\title{
Adapting Grice's Conversational Implicature in the Listening Comprehension of CET-4
}

\author{
Xiaoyang Shu \\ Teaching Center, Zhejiang Open University, Hangzhou, China \\ Email: sxy327love@126.com
}

How to cite this paper: Shu, X.Y. (2021) Adapting Grice's Conversational Implicature in the Listening Comprehension of CET-4. Open Access Library Journal, 8: e8232. https://doi.org/10.4236/oalib.1108232

Received: November 26, 2021 Accepted: December 26, 2021 Published: December 29, 2021

Copyright $\odot 2021$ by author(s) and Open Access Library Inc.

This work is licensed under the Creative Commons Attribution International License (CC BY 4.0).

http://creativecommons.org/licenses/by/4.0/

\section{(c) (i) Open Access}

\begin{abstract}
This paper aims to analyze the short conversations in the listening comprehension of CET-4 from the perspective of pragmatics. Grice's conversational implicature can be adapted to the teaching of listening by providing both teachers and students with a way of how particular utterance meanings are conveyed and decoded in specific contexts of situation, which can both enhance the students' language use ability and improve their performance on the listening test of CET-4. In this paper, through interview and categorizing some real test items which can be interpreted from the pragmatics perspective, the author argues that although the students' inadequate practices and limited vocabulary partly account for the errors made in these tests, ignorance of unfamiliarity with pragmatics theories is also an important contributor to test mistakes.
\end{abstract}

\section{Subject Areas}

Linguistics

\section{Keywords}

Listening Comprehension, Conversation, CET-4, Grice's Conversational Implicature

\section{Introduction}

The points discussed here had their origins in the kind of problem faced by many English teachers: in the part of short conversations in the listening comprehension section of CET-4, a student understands the vocabulary and grammar of a conversation, but he still fails to choose the correct answer. Just such a problem with a student's listening comprehension gave rise to the issues to be considered in this paper. Taking an overview of the listening comprehension 
section of CET-4, we find that items involving Grice's conversational implicature account for a large percentage. However, owing to a lack of theoretical guidance in this aspect, students have some difficulty in dealing with these kinds of questions.

With Bouton (1988), a student's unawareness of a particular culture may cause the student to derive different interpretations of culture-specific implicature [1]. Furthermore, in 1990, Bouton found that almost no attention is spent on the students' awareness of implicature and contended that implicature can and should be taught in the classroom [2].

The author will begin by reviewing Grice's conversational implicature and cooperative principle. In the second part, in considering the implicature of culturally-related expectations for the teaching of listening comprehension, the author will discuss the applicability of Grice's conversational implicature to listening. For each of these principles, several real test items, which can be interpreted from a pragmatics perspective, are categorized. Finally, through the interview and questionnaire, the author concludes that although the students' inadequate practices and limited vocabulary partly account for the errors made in these tests, ignorance of unfamiliarity with pragmatic theories is also an important contributor to test mistakes.

\section{Grice's Theory on Conversational Implicature and Cooperative Principle}

The implicit meaning implied by utterances in conversation is called conversational implicature [3], which is one of the most important manifestations of indirect language. To understand the speaker's real intention of his utterances, the hearer has to make a series of inferences from both the literal meaning of the utterances and the context involved in his interlocution with the speaker. In a word, conversational implicature means that the hearer, according to cooperative principle, infers the speaker's implicit meaning, not literal meaning in utterances [4].

In an attempt to know the way the hearers infer meanings and intentions rather than those that are obvious from the surface language, Grice [5] put forward the Cooperative Principle in 1975. Under the CP, there are four maxims:

1) Quantity

a) Make your contribution as informative as required.

b) Do not make your contribution more informative than is required.

2) Quality

a) Do not say what you believe to be false.

b) Do not say that for which you lack adequate evidence.

3) Relation

a) Be relevant.

4) Manner

a) Avoid obscurity of expression.

b) Avoid ambiguity. 
c) Be brief.

d) Be orderly.

\section{Grice's Conversational Implicature and Listening Comprehension}

\subsection{Data Collection}

Why can't many people make a quick and correct judgment on the speaker's utterances in conversation? Why can't the students choose the correct answers when doing the listening comprehension of CET- 4 ? With these questions, the author interviewed about 100 students (non-major English students), which can somewhat represent the common difficulties of the students. And a listening test (some real CET-4 items in listening comprehension section) is administered to these 100 students. Besides, a questionnaire is given to them after this test, including their habits of listening practice, their difficulties of listening practice such as grammar, syntax, phonology, inferring the implicit meaning of the speaker, and the strategies of listening practice.

\subsection{Data Analysis}

With the interview, the fact is that $90 \%$ of the less successful students (refer to: students whose test scores are below 70) complain that the limited vocabulary and unfamiliar with grammar, syntax and phonology are the main reasons to obscure their listening comprehension, while $80 \%$ of the good students (refer to: students whose test scores are over 70) hold that their difficulty in inferring the implicit meaning of the speaker accounts for the low scores in listening section of CET-4. In a word, grammar and vocabulary are partly involved in low scores in listening section, especially to the less successful students. However, besides grammar and vocabulary, unfamiliarity with pragmatic theories, such as conversational implicature and cooperative principle, is also an important contributor to test mistakes, especially with the increase of such questions that are for testing the students' overall language use ability.

With the listening test, some evidences show that the students, whether good students or less successful students, get low scores in this test. About 20 questions, only $5 \%$ of the students get above 80 , and $35 \%$ of the students get over 60 , and the rest is below 60 . From the results, we can't deny that inadequate listening comprehension should partly account for the errors made in these questions, but through the analysis, the main reason is the students' difficulty in inferring the speaker's implicit meaning. Some examples are as follows:

1) M: I think it's high time we turned our attention to the danger of drunk driving now.

W: I can't agree with you more. You see, countless innocent people are killed by drunk drivers each year.

Q: What does the woman mean?

A) Most people killed in traffic accidents are heavy drinkers. 
B) She does not agree with the man.

C) Drunk drivers are not guilty.

D) People should pay more attention to the danger of drunk driving.

Most students choose answer B because this woman answers "I can't agree with you more." They had thought this woman doesn't agree with the man, but in fact, this woman flouts the maxim of manner since her answer seems not to be perspicuous. The author believes if the woman answers "yes," most of the students can choose the correct answer D; therefore, we can infer the conversational implicature from violating the maxim of manner.

2) W: Did you find the book for your reading assignment in the library?

M: It closed before I got there. I had no idea that it closes so early on weekends.

Q: What does the man mean?

A) He didn't get the book he needed. B) He had no idea where the book was.

C) The library is closed on weekends. D) He was not allowed to check out the book.

Clearly, in this conversation, the words are easy and sentence is simple, while many students still find it difficult to choose the correct answer, some of them choose to answer C. If the man answers "no," directly, it is certain that all of the students can choose to answer A. Thus, we should know how to infer the speaker's implicit meaning from his indirect language.

\subsection{The Approach to Inferring the Conversational Implicature}

Bouton [2] held that implicature could and should be taught in the classroom and suggested that it be the responsibility of the instructor to develop it. Therefore, as the teachers, we should develop the students' language use ability. And teaching the students to analyze the implicature is a good way to improve the students' performance on the listening section of CET-4. There are two ways:

1) Inferring the conversational implicature from violating cooperative principle

Firstly, the students should know whether the speaker violates the cooperative principle purposely or not. And if the speaker violates it purposely, what is the conversational implicature on earth? Here is an example:

Mrs. Bennet: My dear, Mr Bennet, have you heard that Netherfield Park is let a last?

Mr. Bennet: No.

Mrs. Bennet: But it's. Mrs. Long has just been here, and she told me all about it.

Mr. Bennet: (no answer)

From this conversation, because Mr. Bennet flouts the maxim of quantity purposely, we can infer that he has no interest in what Mrs. Bennet said. Also, the author has made such example about this approach in the above.

2) Inferring the conversational implicature according to context 
As we know, there are different conversational implicatures in different contexts, which will enhance the difficulty of listening comprehension. Therefore, we should choose the correct conversational implicature according to the specific context. Here is an example:

M: If you don't have an account here, I can't cash your check. I am sorry, but that's the way it is.

W: Well, thanks a lot! You're a big help.

Q: How does the woman feel?

A) The woman is helpful. B) The woman is thankful.

C) The woman is offended. D) The woman is sorry.

Many students choose to answer A or B. Obviously, they choose the answer according to the literal meaning, in fact, and we should take the specific context of this conversation into account. In reality, the woman satirized the man by saying "Thanks a lot! You're a big help." If this conversation was changed as follows:

M: I have found an English-Chinese dictionary for you, Mary.

W: Well, thanks a lot! You're a big help.

Q: How does the woman feel?

A) The woman is helpful. B) The woman is thankful.

C) The woman is offended. D) The woman is sorry.

Now, this woman's implicature has changed with the change of the context. So the correct answer should be answer B.

In a conclusion, the same utterances have different implicatures in different contexts. The instructors should teach the students how to infer the conversational implicature from violating cooperative principle; furthermore, they should make the different choices according to the different contexts.

\section{Conclusion}

Listening competence figures as an essential measure in examining a foreign language learner's overall linguistic sense and communicative competence [6], and therefore, in the CET-4, the listening comprehension section receives extensive attention from many English teachers due to the students' low scores in this section. In this paper, the author argues that because the "pragmatic items" accounts for a large percentage in the listening comprehension section of CET-4, much attention should be spent on raising the students' awareness of implicature since Grice's theories can explain how native speakers work out the implied meanings of their interlocutors and speakers rely heavily on the cooperative principle when interpreting utterances that involve implicature [7]. In short, the teacher is responsible for teaching the students how to work out utterances involving implicature by direct application of Grice's theories if they are to answer the listening comprehension of CET-4 with any degree of success.

\section{Acknowledgements}

My thanks to the anonymous reviewers for reading and commenting on the ear- 
ly drafts of this article.

\section{Fund Project}

The project is supported by the Scientific Research Projects of Open University of China (Grant No. G18A1603Y), the Teaching Reform Project of Zhejiang Open University (Grant No. XJG202105).

\section{Conflicts of Interest}

The author declares no conflicts of interest.

\section{References}

[1] Bouton, L.F. (1988) A Cross-Cultural Study of the Ability to Interpret Implicature in English. World English, 7, 183-196. https://doi.org/10.1111/j.1467-971X.1988.tb00230.x

[2] Bouton, L.F. (1990) The Effective Use of Implicature in English: Why and How It should Be Taught in the ESL Classroom. Pragmatics and Language Learning Monograph Series, 1, 43-52.

[3] Levinson, G.F. (1983) Principles of Pragmatics. Longman, London. https://doi.org/10.1017/CBO9780511813313

[4] He, Z. (1997) Pragmatics and English Learning. Shanghai Foreign Language Education Press, Shanghai.

[5] Grice, H.P. (1975) Logic and Conversation. In: Cole, P. and Morgan, J., Eds., Syntax and Semantics, Vol. 3, Speech Acts, Academic Press, New York, 41-58. https://doi.org/10.1163/9789004368811_003

[6] Buckhoff, M. (2004) Teaching Students Implied Meaning for TOEFL Preparation Listening. https://buckhoff.topcities.com/UCRpresentation.htm

[7] Ge, L. (2002) Teaching Pragmatics. National University of Defense Technology Press, Beijing. 


\section{Appendix 1}

(Some Real CET-4 Items in Listening Comprehension Section)

1. M: I think it's high time we turned our attention to the danger of drunk driving now.

W: I can't agree with you more. You see, countless innocent people are killed by drunk drivers each year. Q: What does the woman mean?

A) Most people killed in traffic accidents are heavy drinkers. B) She does not agree with the man.

C) Drunk drivers are not guilty. D) People should pay more attention to the danger of drunk driving.

2. Mary, would you like to go to the movies with me after dinner?

W: Well, I'll go if you really want me to. But l'm rathertired. Q: What can we conclude from this conversation?

A) The woman does not want to go to the movies. B) The man is too tired to go to the movies.

C) The woman wants to go to the movies. D) The man wants to go out for dinner.

3. W: What do you think of the apple pie? I made it myself.

M: Very delicious indeed. Even my mother's cannot match this. Q: What does the man mean?

A) This apple pie tastes very good. B) His mother likes the pie very much.

C) This pie can't match his mother's. D) His mother can't make apple pies.

4. M: The music is so beautiful that I'd like to dance. But I don't know the steps.

W: It doesn't matter. No one will be looking at us in his crowd.

Q: What does the woman suggest they do?

A) Take a walk. B) Give a performance. C) Listen to the music. D) Dance to the music.

5. W: Mary is always complaining about her job. M: Maybe if you try typing letters every day, you'd see what it's like. Q: What does the man mean?

A) The woman would understand if she did Mary's job. B) The woman should do the typing for Mary.

C) The woman should work as hard as Mary. D) The woman isn't a skillful typist.

6. M: I bought a few books at the new bookstore. Would you like to have a look at them?

W: A few? It looks like you bought out the bookstore Q: What does the woman mean?

A) She didn't like the books the man bought. B) There wasn't a large selection at the bookstore.

C) The man bought a lot of books. D) She wanted to see what the man bought.

7. W: Did you find the book for your reading assignment in the library?

M: It closed before I got there. I had no idea that it closes so early on week- 
ends.

Q: What does the man mean?
A) He didn't get the book he needed. B) He had no idea where the book was.
C) The library is closed on weekends. D) He was not allowed to check out the book.

8. W: John, are you doing research for Professor Williams this semester?

M: Actually, I am working as his teaching assistant. Q: What does the man mean?

A) He needs another job as research assistant. B) He asked Professor Williams for assistance.

C) He assists Professor Williams with his teaching. D) He is doing research with Professor Williams.

9. W: Mrs. Long's briefing seems to go on forever. I was barely able to stay awake.

M: How could you sleep through that? It was very important for the mission we were going to carry out.

Q: What does the man imply?

A) Mr. Long's briefing was unnecessarily long. B) The woman should have been more attentive.

C) Mr. Long's briefing was not relevant to the mission. D) The woman needn't have attended the briefing.

10. W: I'm thinking of taking five courses next semester. M: Wouldn't four be wiser?

Q: What does the man mean?

A) There are too many courses offered to students. B) The woman should take fewer courses next term.

C) The man will take four courses next semester. D) It is wiser to take more than four courses.

11. M: Is Jane looking forward to going home for the summer? M: She is counting the days.

Q: What does the woman imply?

A) Jane is looking for a summer job. B) Jane is packing for the summer vacation.

C) Jane is on her way home. D) Jane is eager to go home for the vacation.

12. W: I ought to call Joan, and tell her about the reception this evening.

M: Why bother? You will see her at lunch. Q: What does the man mean?

A) She can tell Joan when she sees her at noon. B) She should tell Joan's brother about the reception.

C) She must call on Joan after the reception. D) She may see Joan's brother at lunch.

13. M: Would you like a copy of professor Smith's article? W: Thanks, if it's not too much trouble. Q: What does the woman imply? A) She is not interested in the article. B) She has given the man much trouble. C) She would like to have 
a copy of the article. D) She doesn't want to take the trouble to read the article.

14. M: Wouldn't you get bored with the same routine year after year teaching the same things to children? W: I don't think it would be as boring as working in an office. Teaching is most stimulating. Q: What does the woman imply about office work?

A) It's awfully dull. B) It's really exciting. C) It's very exhausting. D) It's quite challenging

15. W: When will you be through with your work, John?

M: who knows? My boss usually finds something for me to do at the last minute.

Q: What do we learn from the conversation?

A) The man needs help. B) The man is complaining.

C) The man likes his job D) The man is talking with his boss.

16. M: How did you like yesterday's play?

W: Generally speaking, it was quite good. The part of secretary was played wonderfully, but I think the man who played the boss was too dramatic to be realistic.

Q: How does the woman feel about the man? A) He played his part quite well. B) He was not dramatic enough. C) He preformed better than the secretary D) He exaggerated his

17. W: Mr Jones, your student, Bill, shows great enthusiasm for music instruments.

M: I only wish he showed half as much for his English lessons.

Q: What do we learn from the conversation about Bill? A) He is not very enthusiastic about his English lessons. B) He has made great progress in his English.

C) $\mathrm{He}$ is a student of the music department. D) He is not very interested in English songs.

18. M: Jessica, could you this emails to all the club members?

W: Sorry, the computer broke down this morning. I will for you as soon as I have fixed.

Q: What does the woman imply?

A) She has to post a letter instead. B) She has to turn down the man's request.

C) She's not sure if the computer is fixed. D) She can't send the message right now.

19. M: Would you get me through to Dr. Lemon please?

W: I'm sorry. He's with a patient. Q: What does the woman mean?

A) Dr. Lemon is waiting or a patient. B) Dr. Lemon is busy at the moment.

C) Dr. Lemon has lost his patience. D) Dr. Lemon has gone out to visit a patient

20. W: Have you finished reading my research report. I put it on your desk last week.

M: Yes, but you have to revise some parts of it, I'm afraid, if you want to get it 
published.

Q: What does the man suggest that the woman should do?

A) Put her report on his desk. B) Read some papers he recommended.

C) Improve some parts of her paper. D) Mail her report to the publisher. 